\title{
Advances in passion fruit (Passiflora spp.) propagation
}

Fábio Gelape Faleiro ${ }^{1}$, Nilton Tadeu Vilela Junqueira ${ }^{2}$, Tatiana Góes Junghans ${ }^{3}$, Onildo Nunes de Jesus ${ }^{4}$, Diego Miranda ${ }^{5}$, Wagner Campos Otoni ${ }^{6}$

\begin{abstract}
The propagation of many passion fruit species (Passiflora spp.) is done by seeds or sexual method, although asexual propagation, such stem cuttings, grafting or tissue culture is also possible and very useful in many cases. In this work, it was presented information on scientific and technological advances in sexual and asexual propagation of passion fruit, considering the different propagation methods and their applications. New demands for research and development activities are also related, given the wide range of passion fruit species and its potential for food, ornamental and medicinal use.
\end{abstract}

Index terms: seed germination, vegetative propagation, cuttings, grafting, tissue culture.

\section{Avanços na propagação do maracujazeiro (Passiflora spp.)}

Resumo - A propagação da maioria das espécies de maracujá (Passiflora spp.) utilizadas para fins alimentares é feita por via sexuada, embora a propagação assexuada, a exemplo de mudas obtidas por estaquia, enxertia ou cultura de tecidos também seja possível e muito útil em muitos casos. Neste trabalho, são apresentadas informações sobre os avanços científicos e tecnológicos na propagação sexuada e assexuada do maracujazeiro, considerando os diferentes métodos de propagação e suas aplicações. Novas demandas para as ações de pesquisa e desenvolvimento também são levantadas, considerando as diferentes espécies de maracujá e suas potencialidades de uso alimentar, ornamental e medicinal.

Termos para indexação: germinação de sementes, propagação vegetativa, estaquia, enxertia, cultura de tecidos.

\footnotetext{
Corresponding author:

fabio.faleiro@embrapa.br

Received: June 08, 2018

Accepted: September 21, 2018

Copyright: All the contents of this journal, except where otherwise noted, is licensed under a Creative Commons Attribution License.
}

${ }^{1}$ Agronomist, Doctor in Genetics and Breeding, Researcher of the Embrapa Cerrados, Planaltina-DF, Brazil, E-mail: fabio.faleiro@ embrapa.br ${ }^{\text {(ORCID 0000-0001-8901-6428) }}$

${ }^{2}$ Agronomist, Doctor in Phytopathology, Researcher of the Embrapa Cerrados, Planaltina-DF, Brazil, E-mail: nilton.junqueira@embrapa.br ${ }^{\text {(ORCID }}$ 0000-0001-9814-7104)

${ }^{3}$ Agronomist, Doctor in Plant Physiology, Researcher of the Embrapa Mandioca e Fruticultura, Cruz das Almas-BA, Brazil, E-mail: tatiana. junghans@embrapa.br ${ }^{\text {(ORCID 0000-0002-6880-9557) }}$

${ }^{4}$ Agronomist, Doctor in Genetics and Breeding, Researcher of the Embrapa Mandioca e Fruticultura, Cruz das Almas-BA, Brazil, E-mail: onildo.nunes@embrapa.br (ORCID 0000-0003-1145-8028)

${ }^{5}$ Agronomist, Doctor in Plant Physiology, Prof. of Agronomy Faculty, National University of Colombia, Bogotá, Colombia, E-mail: dmirandal@

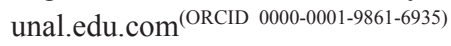

${ }^{6}$ Agronomist, Doctor in Genetics and Breeding, Prof. Departament of Plant Biology, Federal University of Viçosa, Viçosa, Brazil, E-mail: wotoni@ufv.br ${ }^{(\text {ORCID 0000-0002-9614-9373) }}$ 


\section{Introduction}

Passion fruit is the general name given to several species of Passiflora. It is estimated that the Passiflora genus has more than 500 species with most of them producing fruits for in natura consumption and industrial processing, flowers with an exuberant beauty and great ornamental potential, besides presenting phytoconstituents in different parts of the plant that might be used for medicinal properties. Most of the species are found in Tropical America, including Brazil, Colombia, Peru, Ecuador, Bolivia and Paraguay, although there are native species from the United States to Argentina, besides Asia, Australia and China. Since there are over 100 endemic species in Brazil, passion fruit is considered part of the Brazilian biodiversity (BERNACCI et al., 2015; FALEIRO; JUNQUEIRA, 2009).

Numerous species of passion fruit (Passiflora spp.) are commercially grown generating jobs and revenue in the cities and country side (Figure 1). Brazil and Colombia are the most traditional countries growing passion fruit (BERNACCI et al., 2005) and presenting high economic and social relevance, serving as an alternative crop mainly for family-based agriculture.
In Brazil, Passiflora edulis Sims (sour passion fruit, yellow passion fruit, 'maracuya') is found in over $90 \%$ of the orchards. Other species grown in Brazil include $P$. alata Curtis (sweet passion fruit, maracujá-açu, maracujámamão), P. setacea DC. (maracujá do sono, maracujá do cerrado, maracujá pérola, maracujá sururuca, maracujá de cobra) and P. cincinnata Mast. (maracujá do mato, maracujá da caatinga) that also reach a commercial level as fruit tree. Besides that, other species such as P. edulis Sims f. edulis (maracujá roxo nativo), P. nitida Kunth (maracujá suspiro, maracujá do cerrado), P. quadrangularis L. (maracujá gigante, 'badea', maracujá de quilo) and $P$. maliformis L. ('cholupa', 'granadilla de piedra') are locally or domestically grown. Another chain supply that has gaining strength in Brazil is the use of interspecific hybrids for ornamental purposes being already a tradition in some European countries (FALEIRO et al., 2015).

In Colombia, six species of passion fruit are commercially grown being $P$. ligularis Juss. ('granadilla') the most traditional. Other species include $P$. edulis Sims, P. edulis Sims f. edulis ('gulupa', maracujá-roxo), $P$. maliformis L., P. tripartita Poir. var. mollissima (Kunth) Holm-Niels. \& P. Jørg. ('curuba', 'tumbo') and $P$. quadrangularis L. ('badea') (MIRANDA et al., 2009).
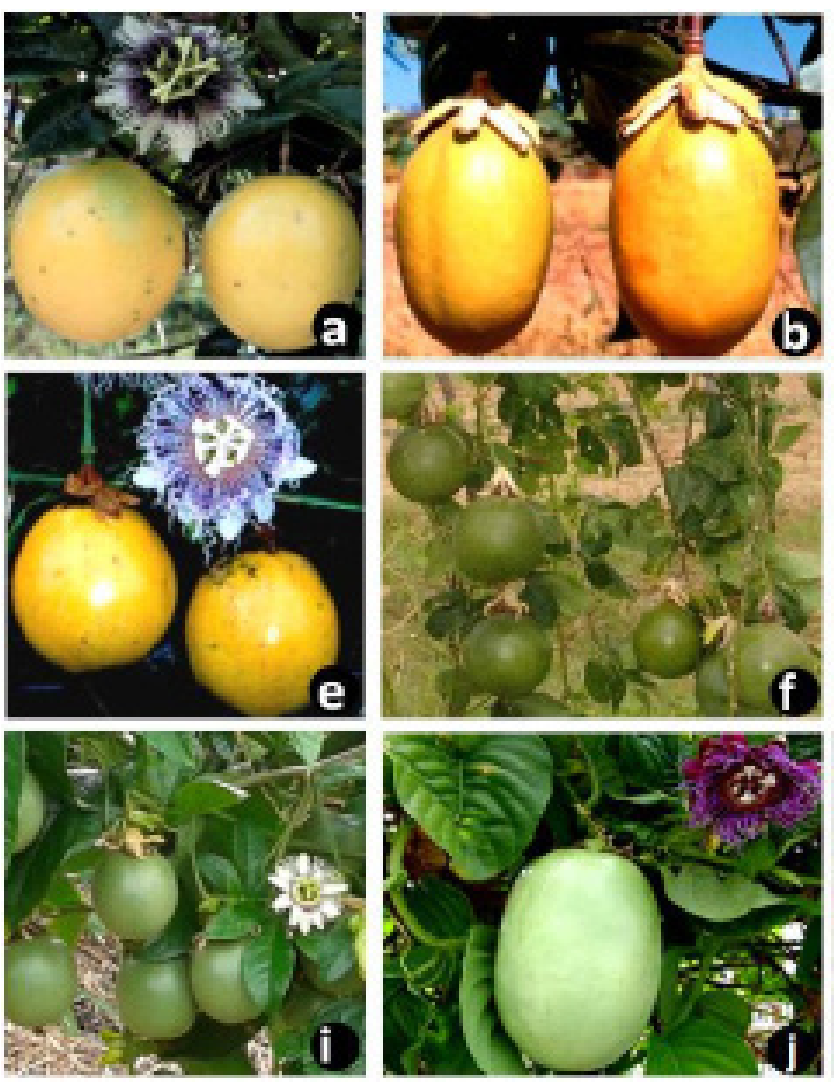
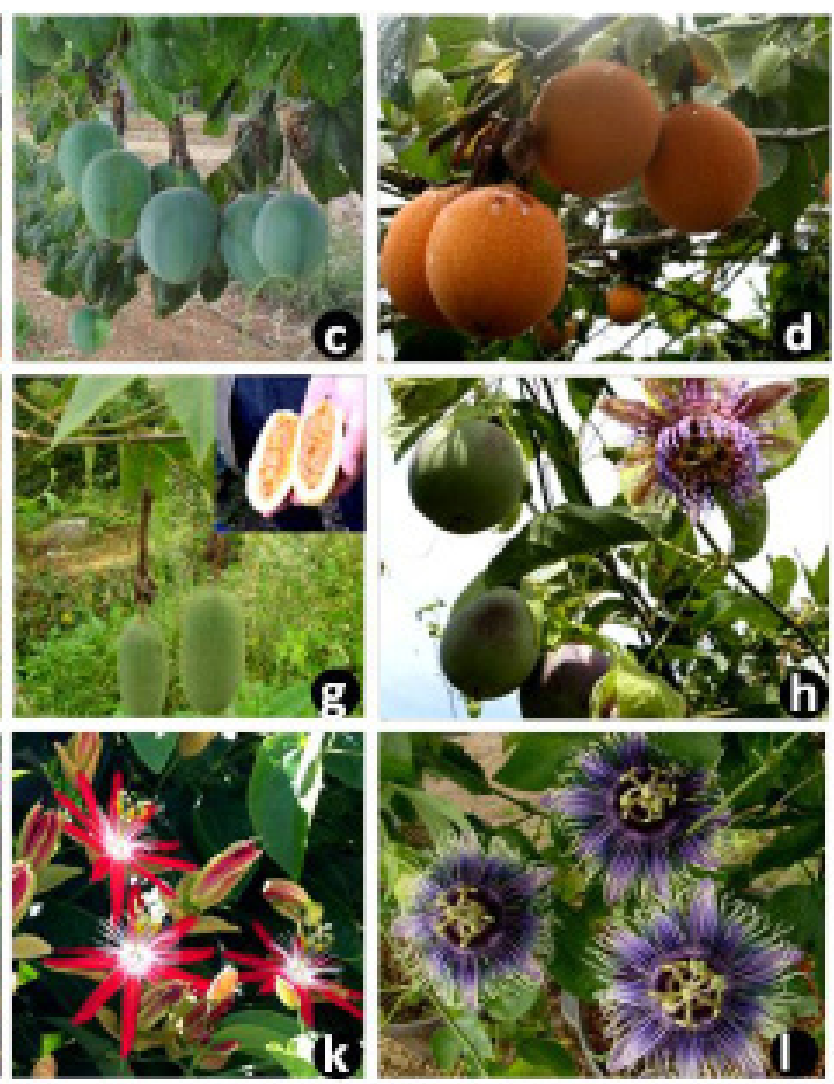

Figure 1. Main commercial species Passiflora: P. edulis Sims (a); P. alata Curtis (b); P. setacea DC. (c); P. ligularis Juss. (d); P. nitida Kunth (e); P. cincinnata Mast. (f); P. tripartita (Juss.) Poir. (g); P. maliformis L. (h); P. edulis Sims f. edulis (i); P. quadrangularis L. (j); P. setacea $x$ P. coccinea cv. BRS Estrela do Cerrado ornamental hybrid (k); $P$. edulis $x$ P. incarnata cv. BRS Céu do Cerrado- BRS CC ornamental hybrid (1). Photos: Nilton Junqueira, Fábio Faleiro, Ana Maria Costa, Embrapa Cerrados. 
Most commercial species of passion fruit are self-incompatible. Therefore, they need the pollination among different plants for flowering and fruit production. Self-incompatibility has important implications in plant propagation methods since commercial orchards need genetically distinct plants. The propagation method for most of the species used for food is made through sexual reproduction, although asexual propagation, like clone obtained through cuttings, grafting or tissue culture is also possible and very useful in some cases (ALEXANDRE et al., 2004).

In case of sexual reproduction, several species of Passiflora present problems of seed germination. Aspects related to dormancy, recalcitrance, genetic and physiologic quality of the seeds directly influence graft quality to be used in the production system. As for the asexual reproduction, the key factors include genetic and physiologic quality of parent plants, different reproduction methods, types of substrates and treatment with vegetable regulator to improve rooting and the success in graft production. Passion fruit propagation has been the topic of important reviews made by numerous authors including SÃO JOSÉ (1991), SIQUEIRA and PEREIRA (2001); ALEXANDRE et al. (2009). To complement previous reviews, this present work provides information about scientific and technological advances in sexual and asexual propagation of passion fruit, considering different methods of reproduction and their application. New demand for the research and development of actions are also studied considering different species of passion fruit and their food, ornamental and medicinal potential.

\section{SEXUAL PROPAGATION}

\section{Principles and applications in passion fruit}

Seed propagation is the most used method for a great number of Passiflora species commercially grown, especially the ones used as food. The several advantages of this method include simple seedlings production process, shorter formation time, less demand for labor and infrastructure in the orchard, simpler logistic concerning seeds commercialization and transportation and the possibility to produce seedlings free from phytopathogens that are not transmitted by seeds, mainly the virus that cause serious problems for passion fruit growers. Another important point for the process of obtaining plants from seeds is the guarantee that it will produce plants genetically distinct in the orchard avoiding issues like a low set of flower and fruits and pulp production. This would be caused due to a difficult pollination and cross-fecundation because of the genetic self-incompatibility that occurs in most of the grown passion fruit species. Of course, plants produced from seeds might show a high genetic variability that may cause an uneven orchard resulting in a decreased commercial value of fruits and making difficult the different crop handling practices.
It is also fundamental to mention the relevance of sexual propagation in genetic improvement, considering the possibility of combining in only one seed different characteristics of interest through an intra and interspecific hybridation process followed by recombination and selection cycles. Another important application of sexual propagation is the fact that it is easier to keep genetic resources through orthodox seeds, that is, seeds that keep their germination capacity even when stored in low temperatures and humidity.

\section{Germination and seed storage}

There has been accurate information on seed germination and storage from different species of Passiflora mainly in Passiflora edulis Sims that shows the highest economic relevance. One can say that this information is still incipient, considering the huge diversity of Passiflora that displays different characteristics for seed germination and storage (JUNGHANS, 2015). Besides the differences within species, there are differences between distinct accessions or cultivars in the same species (ALEXANDRE et al., 2004). Several other factors also influence seed germination and storage, including quality and physiological maturity (NEGREIROS et al., 2006), presence or absence of dormancy (PÁDUA et al., 2011; SANTOS et al., 2012a; REGO et al., 2014) and different methods of seed extraction, processing and storage (PEREIRA e DIAS, 2000; OSIPI et al., 2011; MELETTI et al., 2007; PÁDUA et al., 2011).

In general, studies about seeds from different species of Passiflora have found that germination is low and irregular, that is, there is a long period between the beginning and end of germination resulting in uneven seedlings which becomes a problem when cultivating the species (SOUZA e MELETTI, 1997). Another common finding is the fact that seeds from many passion fruits are recalcitrant and rapidly lose their viability at room temperature. In different storage conditions, besides the decrease in germination speed and vigor, a decrease in the percentage of germination is also common (SANTOS et al., 2012a; GURUNG et al., 2014).

One of the causes for low and uneven germination is the different physiologic maturity and quality of the seeds. Many passion fruit species show continuous flowering generating an uneven fruit maturity stage that can result in different physiological maturity of seeds (SANTOS et al., 2016a). In this context, the time of harvest to collect seeds is very important. Certainly, this time of harvest will vary among Passiflora species. For instance, NEGREIROS et al. (2006) found that for sour passion fruit (P. edulis Sims), seed extraction should be made in fruits showing maturity stage 2 (fruit with 5\% to 50\% yellow color) and stage 3 (fruits showing over $50 \%$ of yellow color). Besides the time of harvest, the post-harvest storage period might bring advantages in relation to the seed physiological maturity 
and quality. NEGREIROS et al. (2006) observed a better physiological quality of seeds extracted from the fruits of $P$. edulis after 3 to 6 days of storage. AGUACÍA et al. (2015) also found out an important maturation effect of fruits and fermentation period of seeds in the percentage and speed of germination where the lowest values were obtained from seeds extracted from more mature fruits and submitted to a one day fermentation. Apparently, seeds fermentation decrease the quality of organic substances and inorganic salts in the aryl inhibiting the germination.

Dormancy is also a problem directly related to germination and storage of seeds from different species of passion fruit (ALEXANDRE et al., 2004; PASSOS et al., 2004; DELANOY et al., 2006; PÁDUA et al., 2011). It is the physiological mechanism where viable seeds do not germinate even in adequate conditions of humidity and temperature. This process is an adaptation mechanism for some species that delays seeds germination or that results in germination throughout the time, increasing the possibility of survival and perpetuation of species. It is more common in wild or non-domesticated species since in the domestication process there is a selection of genotypes or processes that result in a high percentage of fast and uniform germination.

Seeds dormancy might be classified as endogenous (caused by factors related to embryos) and exogenous (due to factors related to endosperm, tegument or other barriers imposed by the fruit). It can also be primary or natural (trait inherent to the seed) and secondary or induced (caused by unfavorable conditions to germination) (VIVIAN et al., 2008). Depending on the type of dormancy, it might have different causes, where the most common ones are the presence of germination inhibitors, embryos physiologically immature or rudimentary, impermeability of tegument, besides the combination of different causes. Dormancy breaking includes the use of vegetable regulators, chemical and mechanical scarification of seeds, in vitro embryo germination, treatments with different humidity and temperature conditions and hot water. MIRANDA et al. (2013) reported the current status and some advances in sexual reproduction of important Passiflora species in Colombia, considering their histology, physiology and biochemical activities of seeds, besides different methods of storage and dormancy breaking. In terms of different species of Passiflora, it is impossible to generalize the type of dormancy and treatment to break it, therefore more thorough studies considering the genetic variability of accessions and cultivars within each species are necessary.

Because of this intra and interspecific variability, some controversies as for the germination percentage, presence or absence of seeds dormancy, types of more adequate dormancy breaking treatments, types of more appropriate seeds storage to maintain the viability and vigor of seeds are commonly found in the scientific literature. For instance, MORLEY-BUNKER (1974; 1980) state that some species of Passiflora spp. show dormancy of their seeds due to an impermeable tegument, demanding a treatment to overcome it, while ELLIS et al. (1985) reported that seeds of Passiflora allow the entrance of water but have germination inhibitors. FERREIRA (1998) observed that the seeds of some passion fruits do not avoid water entrance although imbibition time is not the same for each one of the species.

The possibility of storing seeds is essential to keep genetic resources in germplasm banks and facilitate the logistic of producing and commercializing cultivar seeds. A germination analysis in response to the dehydration levels, exposure to low temperatures and relative humidity and pre-germination treatments are fundamental to define better storage strategies and commercial processes to produce plants from seeds. Of course, those responses will vary for each species. There are also variations between accessions and cultivars within the species. PADUA et al. (2011) have found that in the case of Passiflora setacea DC., the seeds are tolerant to desiccation up to levels close to $4 \%$ of water, low humidity and storage temperature induce seed dormancy and that the seeds longevity is higher when stored in temperatures lower than $0{ }^{\circ} \mathrm{C}$. According to OSPINA et al. (2000), the seed humidity content is a critical factor in seeds storage especially in the cryopreservation. Numerous species of passion fruit show intermediary seeds that tolerate dehydration to relatively low levels but that are damaged by temperatures lower than $0{ }^{\circ} \mathrm{C}$ when dried (ELLIS et al., 1990). There are also some recalcitrant species that do not accept dehydration in a humidity level sufficiently low to allow its storage at negative temperatures (MELETTI et al., 2007; VEIGABARBOSA et al., 2013). Certainly, more essays involving different accessions and species need to be carried out to broad and confirm this information.

\section{Plant propagation from seeds}

The physiologic, genetic and phytosanitary quality of seeds is a key factor for the success of plant propagation in order to enable uniform and vigorous seedlings. In some species, seeds might present a low germination percentage due to natural dormancy or dormancy induced by the storage process. In these situations, pre-germination treatments might be necessary. Dormancy breaking for Passiflora setacea DC. cv. BRS Pérola do Cerrado (BRS PC) and Passiflora cincinnata Mast. cv. BRS Sertão Forte (BRS SF) is overcome by treating the seeds with $\mathrm{GA}_{4+7}$ + N-(phenyl methyl)-aminopurine (ZUCARELI et al., 2009; COSTA et al., 2015) vegetable regulators, allowing the commercial production of seedlings and launching of these cultivars (EMBRAPA, 2016a; 2016b).

Besides seed quality, other factors influence seedlings quality including humidity and temperature conditions and type of recipient and substrate (OLIVEIRA 
et al., 1993; BRAGA e JUNQUEIRA, 2003; WAGNER JÚNIOR et al., 2006; LOPES et al., 2007). These factors will influence the time needed to form seedlings as well as vigor, uniformity and plant structures that will influence seedlings setup and development after field transplant.

Humidity and temperature are essential in seeds germination and development of new plants (SANTOS et al., 1999; BRAGA e JUNQUEIRA, 2003; ZUCARELI et al., 2009). Humidity control will affect the plant development, occurrence of diseases and depends on the irrigation handling, water quality, type of recipient and water retention capacity in the substrate used. Temperature directly affects the speed rate of seeds germination and also plants development (ZUCARELI et al., 2009). The type of recipient and substrate also influence seedling production mainly in the initial development of plants (SOUZA et al., 2006; JUNQUEIRA et al., 2014).

The substrate should have characteristics such as high porosity, humidity retention capacity, proper value of $\mathrm{pH}$ and nutrients, capacity of cation exchange, low salinity besides allowing the availability of nutrients for grafts in development (SOUZA et al., 2006). Its composition might vary and include sand, soil, coconut fiber, commercial substrate or a mix of several substrates. As for the recipients, many types have been used to produce passion fruit grafts, where the most common ones are tubes and plastic bags of different sizes (Figure 2). Smaller recipients demand smaller physical space at the orchard and facilitate the logistic related to seedlings commercialization and transportation, while larger recipients with higher amount of substrate allow a higher growth and bigger seedlings, considering the root system and aerial part. In general, larger and more structured seedlings show a lower mortality rate at the field, shorter time of exposition and higher tolerance to pests and diseases (mainly during the most vulnerable stage in the beginning of the development) and higher precocity and productivity (mainly in areas with a higher rate of pests and diseases). Based on these advantages, JUNQUEIRA et al. (2014) reported the technical and economic viability of using the "tecnologia do "mudão" (a technology where the plants are over $90-\mathrm{cm}$ tall) for passion fruit (Figure 2).
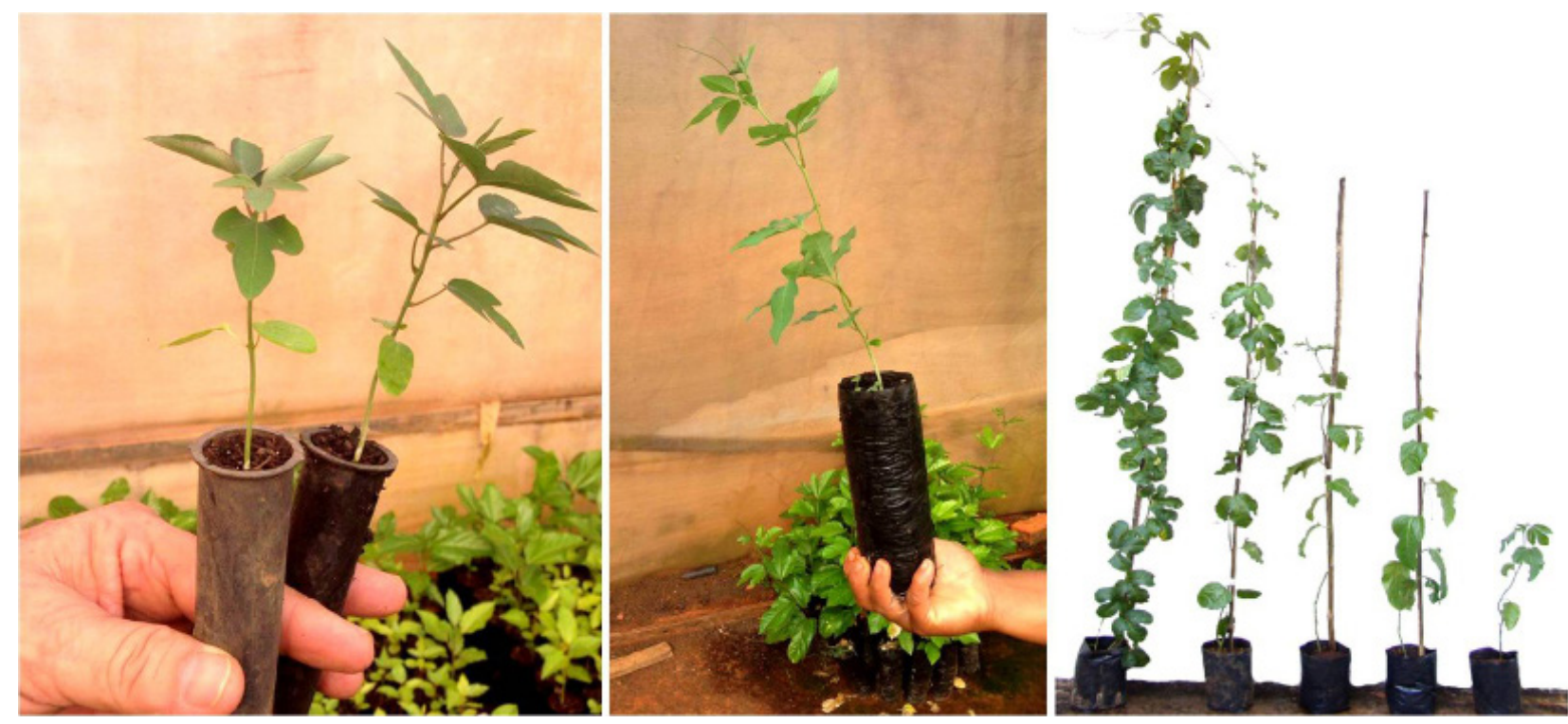

Figure 2. Different recipient and plant sizes of passion fruit obtained through seeds

\section{ASEXUAL PROPAGATION}

\section{Principles and applications in passion fruit}

Asexual or vegetative propagation has been studied in many species of Passiflora. Several of the species grown is predominantly propagated through seeds although asexual propagation might be successfully used for most of them. The main advantage of this method is the possibility of cloning mother plants with desirable agronomic traits. When considering sour passion fruit, sweet passion fruit and other species of wild passion fruit, clonal selection of plants with a higher productivity, bigger fruits and higher resistance to diseases selected to produce seedlings by asexual propagation might imply in significant gains in productivity and higher orchard uniformity (JUNQUEIRA et al., 2006). However, one should take into consideration that most of passion fruits species show self-incompatibility. Consequently, in order to establish an orchard via asexual propagation, it is necessary to use propagation materials from different plants to enable a cross-fecundation and therefore the set of flower and fruit production.

Currently, there is a technology to produce passion fruit seedlings through asexual propagation by cutting, grafting and also micropropagation techniques via tissue culture (ALEXANDRE et al., 2009a). These methods have 
not been commercially used for most of the species in a massive way because of their high cost and complexity, longer time to form seedlings, higher labor demand and infra-structure necessary to the orchard and difficulty in producing seedlings free of disease, mainly viral diseases.
The main varieties of ornamental passion fruit already produced in Brazil (EMBRAPA, 2016c; 2016d) are propagated in a vegetative way through cutting to ensure visual identity, productivity and beauty of their flowers and also to allow the early flowering in 40 to 60 -day old plants grown in vases or your own garden (Figure 3). The production of ornamental passion fruit plants through the rooting of herbaceous cuttings has been successfully performed with high rates of setup and production of viable plants (VIANA, 2016).
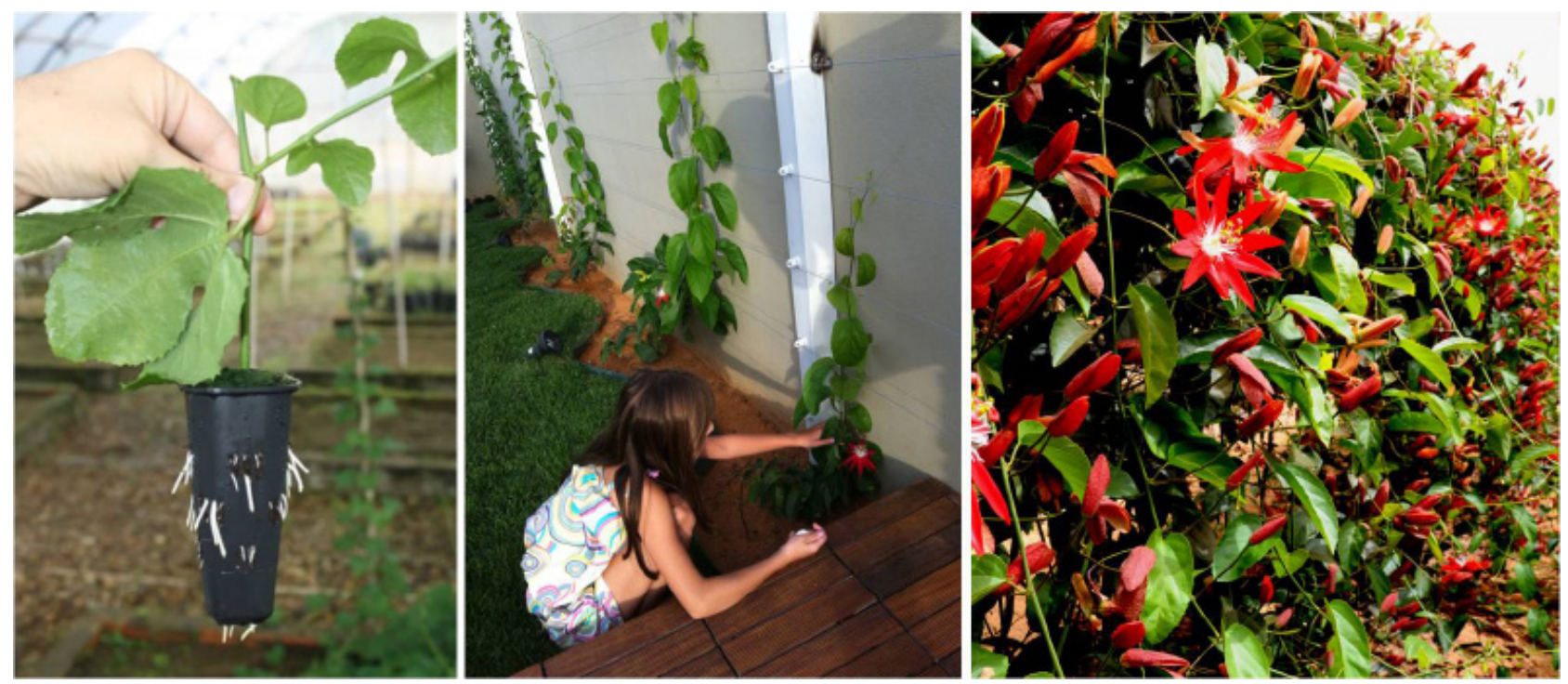

Figure 3. Asexual propagation of ornamental passion fruit tree to maintain productivity, beauty of flowers and flowering precocity.

It is also essential to highlight the importance of asexual propagation in conservation and characterization programs and use of genetic resources. Important accessions of different Passiflora species are kept ex situ in germplasm banks at research institutes. Because there is still a lack of knowledge about the best way to keep seeds from most of the species where some of them are possibly recalcitrant, in general the accessions are kept in vivo in greenhouses, screened greenhouses and in the field. Asexual propagation allows the cloning of these accessions, maintaining their genetic identity and allowing the production of different plants of the same accession, facilitating the characterization and interchange of germplasm and process of renovation in germplasm banks.
This kind of propagation is also important in genetic breeding programs because it allows the cloning of promising genotypes that might be characterized in statistics design with repetitions and in different environments, increasing its accuracy and precision in characterization works. It is also essential in postimprovement activities, enabling the cloning of parents used in the production of sour and sweet passion fruit hybrid seeds (Figure 4). The cloning of selected parents or mother trees is equally fundamental to produce seeds with synthetic varieties, that is, a variety obtained by intercrossing of a group of selected clones or mother trees. This seed production from cloned parents is important to avoid endogamy processes that might occur when the seeds are produced from seeds obtained from a previous orchard. 

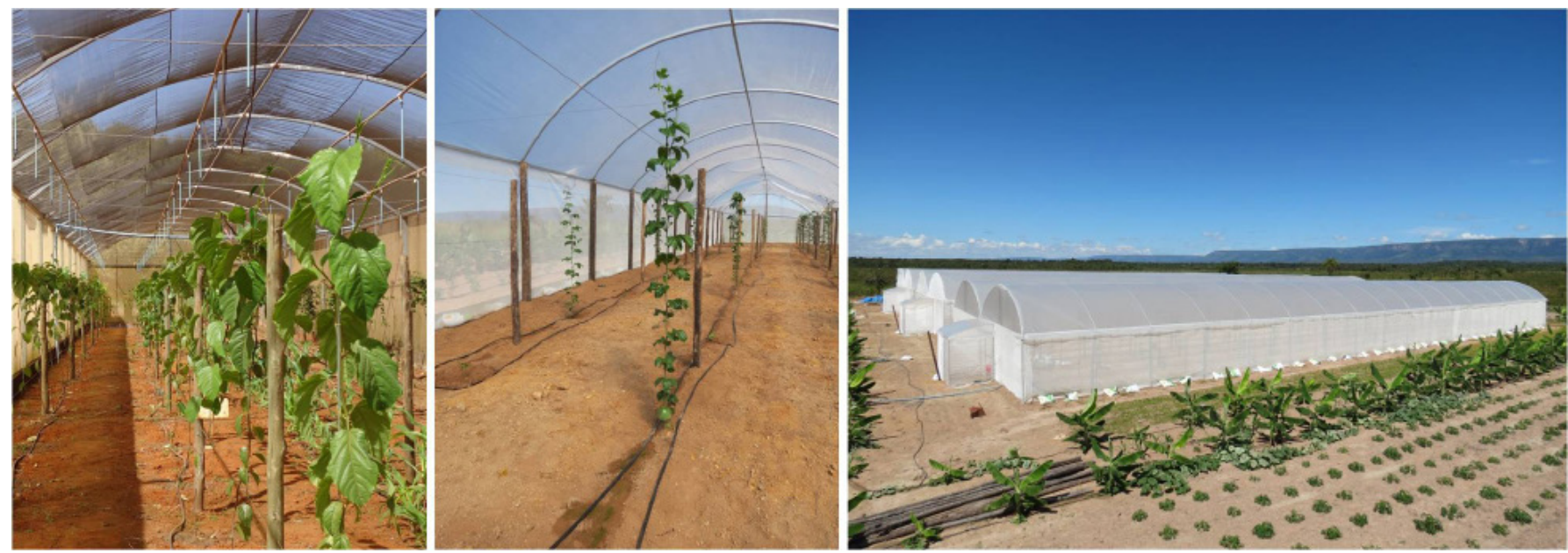

Figure 4. Cloned parents of sweet and sour passion fruit grown in greenhouse through the production of hybrid seeds.

\section{Plant propagation through cutting}

Plant propagation through cutting has been successful in several commercial and wild passion fruits (Passiflora spp.). Rooting of cutting and viable production rates for sour (Passiflora edulis Sims) and sweet passion fruit (Passiflora alata Curtis), that show the highest commercial expression in Brazil, are higher than 90\% (SALOMÃO et al., 2002). Those rates are also high for ornamental passion fruits (VIANA, 2016) evidencing the success of plant propagation through cutting. Several works about rooting of other Passiflora species cutting (PAULA et al., 2005; BRAGA et al., 2006; RONCATTO et al., 2008a; VAZ et al., 2009) have shown the viability of producing new plants through cutting, although the responses vary depending on the species. In some species, the use of vegetable regulators such as indolebutyric acid and adjusts in the used methodologies might considerably increase the success in seedlings production (VAZ et al., 2009; VIANA, 2016).

Many factors might influence the rooting of cuttings rates and success in seedlings production of passion fruit through cutting such as genetic factors in different interspecific species and hybrids (MELETTI e NAGAI, 1992; PAULA et al., 2005; BRAGA et al., 2006; RONCATTO et al., 2008a; VAZ et al., 2009), environmental factors related to different substrates and recipients (OLIVEIRA et al., 1993; JUNQUEIRA et al., 2001; SILVA et al., 2001; OLIVEIRA et al., 2002; REZENDE et al., 2005; SOUZA et al., 2006; SANTOS et al., 2012b), methodologies related to type of cutting used, conditions of humidity and temperature of rooting environment, besides the treatments with synthetic auxins (REZENDE et al., 2005; RONCATTO et al., 2008b; VAZ et al., 2009; ARAÚJO et al., 2010).

Variations in rooting rates and efficacy of vegetative propagation through cuttings within the same species of passion fruit are commonly observed in many scientific papers (SALOMÃO et al., 2002; PAULA et al., 2005), therefore, generalizations related to the success or failure of cuttings are not recommended. These variations might be explained by factors like intra-specific genetic variability, nutritional and phytosanitary conditions of mother plants that will provide the cuttings, harvest time and cutting preparation, besides substrate and rooting environment conditions that might vary a lot in scientific papers. In general, it might be said that the cutting might be successfully made in most of the Passiflora species. However, the optimization of the methodology used might considerably increase the efficacy in seedlings production in different species, accessions and cultivars.

\section{Plant propagation through grafting}

Plant propagation through grafting has been advocated for passion fruit since it combines traits of interest from the root stock and graft. Through the use of grafted seedlings, with the perfect combination of root stock and graft, it is possible to increase the resistance to diseases caused by pathogens that live in the soil, the useful life of orchards and tolerance to water and salt stresses. Besides that, the seedlings contribute to the implementation of agronomically superior orchards in relation to those formed through seeds due to the possibility of having more uniform, productive orchards and fruits with a better quality (RUGGIERO, 1991; MALDONADO, 1991; RUGGIERO e OLIVEIRA, 1998; MACHADO et al., 2015).

In terms of diseases, the most serious ones in sour passion fruit (P. edulis Sims), include wilt and foot rot caused by Fusarium oxysporum f. sp. passiflorae and Fusarium solani, respectively. Currently, there is no cultivar resistant or satisfactory chemical control for these diseases causing the farmers to be disappointed since the infected plants die at the beginning of their productive period. As a consequence, it drastically decreases the productivity and longevity of the culture resulting in economic losses, considering the high investment when implementing an orchard. Based on the facts mentioned above, more researches on technologies to handle these 
diseases caused by Fusarium should be performed (FALEIRO et al., 2006). One of the most promising technologies, the use of wild species of passion fruit as a root stock has been the focus of researches and development in the last years (JUNQUEIRA et al., 2005; JUNQUEIRA et al., 2006; CAVACHIOLI et al., 2011a; 2011b; NOGUEIRA FILHO et al., 2011; RONCATTO et al., 2011; SEMPREBOM et al., 2012; MACHADO et al., 2015).

An important research action is the selection of promising species and cultivars to be used as rootstocks. One of the main characteristics to be considered in the selection process is the resistance to soil pathogens and early death of a plant. The rootstock cultivar should be easy to reproduce, compatible with the graft and provide a fast growth and high productivity of the grafted plant. Many Passiflora species (MENEZES et al., 1994; OLIVEIRA et al., 1994; OLIVEIRA e RUGGIERO, 1998; SANTOS FILHO, 1998; FISHER, 2003; RONCATTO et al., 2004; JUNQUEIRA et al., 2005; CAVICHIOLI et al., 2009a; NOGUEIRA FILHO et al., 2011; ARAÚJO et al., 2012; SEMPREBOM et al., 2012; SILVA, 2016) such as $P$. nitida, $P$. alata, $P$. foetida, $P$. gibertii, $P$. setacea, $P$. cincinnata, P. caerulea, P. macrocarpa, P. quadrangularis, $P$. actnia, $P$. coccinea and numerous interspecific hybrids have been considered as promising species to be used as rootstocks. It is important to highlight that there is a high genetic variability among Passiflora species and Fusarium species. A Passiflora accession or species will not be completely effective in all areas with a history of fusariosis. So, the use of a rootstock will depend on the technology validation in the commercial condition.

Besides choosing the rootstock, the success of grafting will depend on the genotype choice to be used as scion or graft that will present characteristics of high productivity and fruit quality and also resistance to diseases of the aerial part. It is essential that clefts (propagative material used as graft) be collected from different plants to reduce problems related to set of flowers and development of fruits because of the self-incompatibility. This problem can be solved by obtaining clefts from different grafts originated through cultivars seeds of high agronomic performance recommended to the crop area. Generally, each graft provides a cleft although after removing the first cleft, new buds will emerge providing more clefts.

In the search of a higher compatibility between the rootstock and grafts, several grafting methods have been studied. The most used methods were cleft, simple slot or splice graft (MACHADO et al., 2015). Other methods have been reported in the literature such as side grafting, approach grafting, hypocotyledonary grafting and micrografting (LIMA et al., 1999; SANTOS et al., 1999; SILVA et al., 2005; RIBEIRO et al., 2008; RONCATTO et al., 2011a; 2011b; NOGUEIRA FILHO et al., 2005; 2010; 2011; ALEXANDRE, 2013; MACHADO et al.,
2015; SANTOS et al., 2016b).

One of the factors that limit a higher compatibility between the rootstock and graft when commercial species are used in comparison to wild species of Passiflora is the difference in the stem diameter of plants from distinct species obtained through seeds. One alternative to solve this problem is the grafting in rooted cuttings, since they have a larger diameter than the seedlings. The cuttings have an advantage which is the cloning providing a higher uniformity to the obtained grafts (JUNQUEIRA et al., 2002; CHAVES et al., 2004). Another alternative to handle differences in diameters of parts involved in the grafting is the hypocotyledonary graft (NOGUEIRA FILHO et al., 2005; 2010; CAVICHIOLI et al., 2009b; SANTOS et al., 2016b).

A hypocotyledonary graft has been evaluated with different combinations of graft and rootstock and in general has shown results with a high percentage of survival and graft growth (SANTOS et al., 2016b). In this type of grafting, the technique of cleft graft is used and also different tying materials can be successfully utilized (SANTOS et al., 2016b) such as adhesive tape, spring plastic graft clip and metallic hair clip (Figure 5). SANTOS et al. (2016b) state that some advantages in using graft clips includes practical, fast and easy handling, less time to fix it in the rootstock and its reuse after disinfestation. It also decreases the grafting costs and the disposable of plastic tapes debris that might damage the stem growth and can move the graft during its handling. The advantages of the hypocotyledonary graft includes the high graft set, fast multiplication of grafted plants and the possibility of using scions or clefts obtained from newly germinated seedlings, enabling the production of grafted seedlings with higher sanity, genetic variability and shorter time. On the other hand, a hypocotyledonary grafting demands more training from the professional that is handling the graft and an environment that avoids tissue dehydration and allows high graft success rates.

Although the technology used for grafts in Brazil has a great relevance and potential, this propagation method is only slightly used in a commercial level mainly due the lack of rootstock cultivars properly characterized and registered, higher production costs and longer time demanded for graft production. In the last years, some results obtained through research have been validated in commercial production. The use of a selection of $P$. alata as rootstocks in commercial crops in Rio de Janeiro, $P$. nitida and $P$. alata in Mato Grosso, $P$. gibertii in Bahia and $P$. foetida in Rio Grande do Norte should be highlighted (MACHADO et al., 2015). 


\section{Tissue cultures}

Tissue cultures have numerous application in vegetable production, mainly in the propagation process including (DORNELAS e VIEIRA, 1994; LIMA et al., 2000; JUNGHANS et al., 2004; SILVANETO; ANDRADE, 2011; FALEIRO et al., 2012), clonal micropropagation in high level, conservation of in vitro germplasm and clonal cleansing to produce grafts with high phytosanitary quality. There have been several references concerning the micropropagation of many species of Passiflora using different types of explants and culture medium (VIEIRA et al., 2005; OZAROWSKI and THIEM, 2013; OTONI et al., 2013). However, the main factor that limits these methodologies is the low reproducibility of some protocols developed for the culture, since they are specific to the species and sometimes to cultivars (PASSOS; BERNACCI, 2005). This limitation is especially important when the propagation through tissue culture is used, for instance, in the in vitro conservation at germplasm banks formed by different species and accessions.

Direct or indirect organogenesis (APPEZZATODA-GLORIA et al., 1999) has been successfully performed for a great number of Passiflora species using several combinations of growth regulators and types of explants (VIEIRA et al., 2005; FERNANDO et al., 2007; GARCIA et al., 2011; SILVA et al, 2011; VIEIRA et al., 2014). Important advances have also been made in somatic embryogenesis as a source of cells and tissues for protoplasts culture and regeneration of transformed cells (OTONI, 1995; ANTHONY et al., 1999; REIS et al., 2007; SILVA et al., 2009; PINTO et al., 2011; PACHECO et al., 2012; ROCHA et al., 2012; 2015; 2016; ROSA et al., 2015; VIEIRA et al., 2018), as well as the in vitro conservation of germplasm (PACHECO et al., 2016). Figure 6 shows tissue cultures of passion fruit species by organogenesis and somatic embryogenesis.
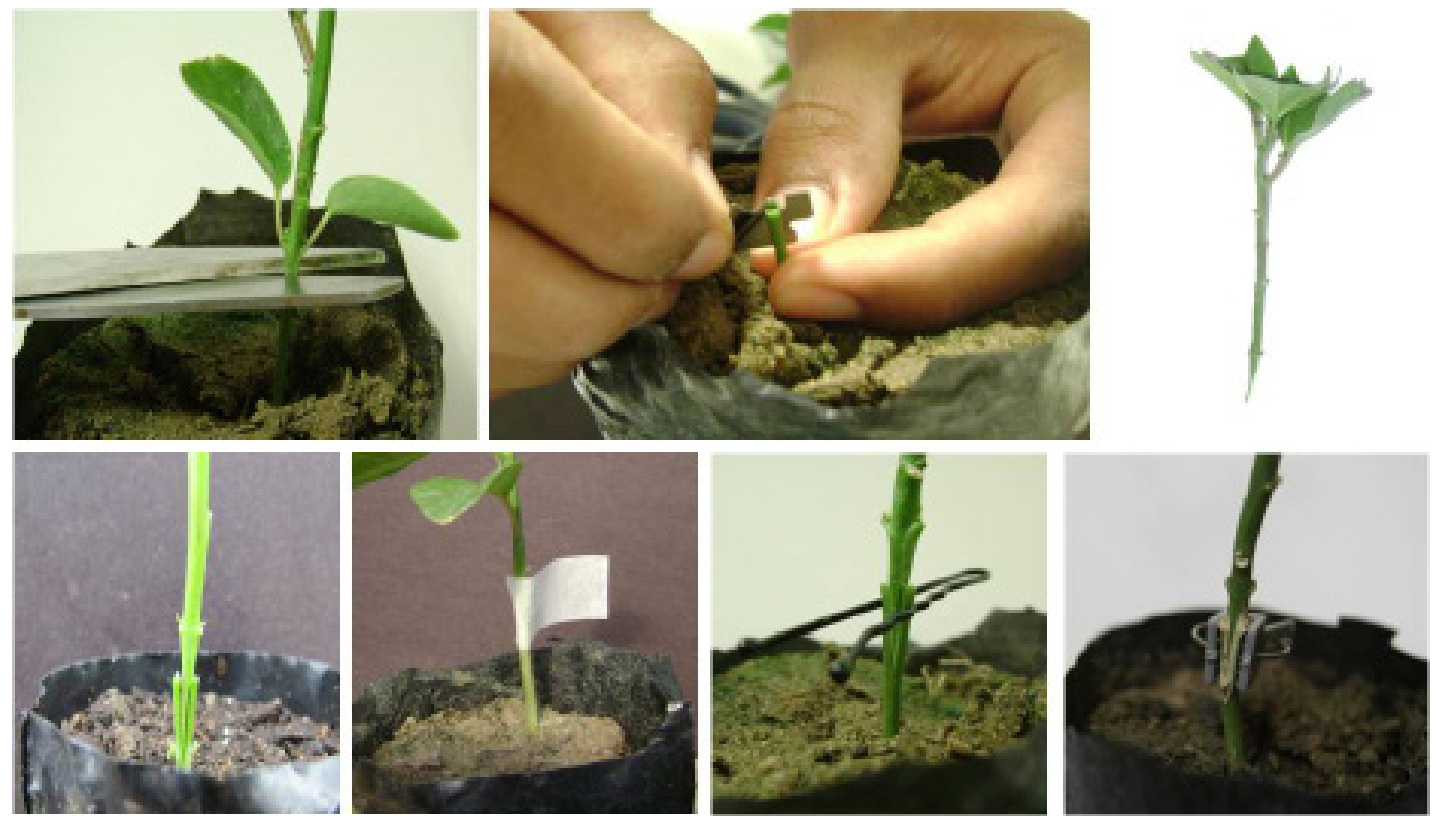

Figure 5. Hypocotyledonary grafting and different types of graft tying.

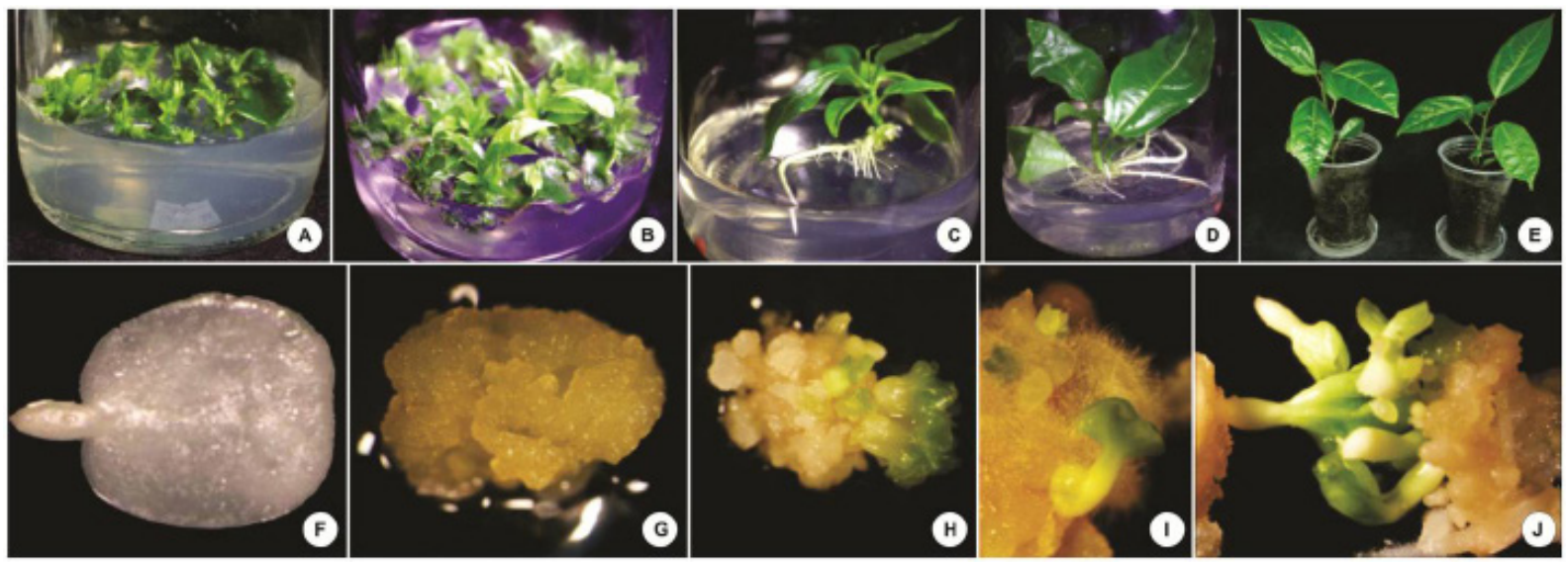

Figure 6. Tissue cultures in Passiflora edulis through adventitious organogenesis (A-E) by using cotyledonal explants and in Passiflora cincinnata through somatic embryogenesis (F-J) from zygotic embryos. 
The in vitro propagation presents a great technological potential for the passion fruit supply chain, mainly in the case of ornamental and medicinal passion fruits, where the maintenance of the genetic identity of plants regarding beauty and number of flowers or production of medicinal phytoconstituents is of great importance (PIPINO et al., 2008; SANTOS et al., 2010; BRAGLIA et al., 2010; OZAROWSKI e THIEM, 2013). In the case of supply chains of sour, sweet and wild passion fruit, clonal micropropagation also has a potential, however, as it occurs on plants resulting from cuttings, one should be careful about implementing an orchard with plants genetically different to avoid problems with self-incompatibility.

Tissue culture also presents applications in the area of propagation such as in vitro seeds germination and embryo rescue (GUZZO et al., 2004; GONZALESBENITO et al., 2009; ALEXANDRE et al., 2009b). Another very important application is the possibility of a clonal cleaning of accessions kept in germplasm banks and also elite mother plants of sour, sweet, ornamental and medicinal passion fruits that are cloned and used for seed or cuttings Productions in graft vegetative production. The most used in vitro technique for this purpose is the culture of meristem or stem apex (PARMESSUR et al., 2002; PRAMMANEE et al., 2011). The principle of this technique is conditioned to obtaining small and avascular apical explants potentially pathogen-free. Micrografting techniques might be used for the clonal cleansing with promissory results for passion fruit (RIBEIRO et al., 2008).

Despite the great technological advances in tissue cultures of different species of passion fruit, the use of technology in the production of grafts is still incipient. Therefore, further basic studies are still necessary to establish the proper culture medium for each tissue culture, besides the methodologies to reduce costs and somaclonal variations that might occur during the production of grafts.

\section{DEMANDS FOR THE RESEARCH OF PASSION FRUIT PROPAGATION}

Important technological advances were achieved in different areas related to the reproduction of different species of passion fruit (Passiflora spp.), however it might be said that there is still a lot to be done in terms of research and development actions, considering the great number of species and interspecific hybrids with a commercial potential and their diversified use in productive chains of sour, sweet, ornamental and functional-medicinal passion fruits.

Seeds storage conditions and possibilities in average and long term and factors that affect seeds germination and grafts productions by sexual and asexual propagation are still not throughly known for many species. Besides the differences among species, there is certainly differences among accessions and varieties within each species that must be studied.

Considering the great importance of vegetable propagation in conservation and characterization of genetic resources programs, breeding programs and also graft production for the different types of passion fruits, mainly ornamental and medicinal passion fruits, the technological advances should be worked with the purpose of optimizing the methodologies used in graft production. The numerous factors that affect this process decreasing costs and increasing its efficacy for different species, accessions and cultivars should be taking into consideration.

As for the asexual propagation through grafts, there is still a lot to be investigated concerning the selection and registration of rootstock cultivars that show immunity to diseases caused by pathogens in the soil, tolerance to water and salt stress, has an easy propagation, compatibility with the graft, besides providing rapid growth and high productivity of scion-graft. As for the methodologies used for grafting, it is fundamental to search for alternatives to decrease the costs involved in the process ensuring the economic viability of technology. Other studies concerning the validation of grafted plants technology in commercial conditions, mainly in areas with a history of biotic and abiotic stresses resulting in the early death of plants, should also be intensified in different regions.

In terms of tissue culture, the scientific advances obtained in the areas of micropropagation, organogenesis, somatic embryogenesis and clonal cleaning of accessions kept in germplasm banks and also some of elite mother trees of passion fruit open important perspectives of economic development related to graft propagation of different types of passion fruit in a high scale and with high genetic and phytosanitary quality.

\section{Acknowledgements}

The authors would like to thank Dr. Carlos Ruggiero for reviewing the article and for the valuable contributions to research actions and development concerning passion fruit propagation. 


\section{References}

AGUACÍA, L.M.; MIRANDA, D.; CARRANZA, C. Effect of fruit maturity stage and fermentation period on the germination of passion fruit (Passiflora edulis $\mathrm{f}$. flavicarpa Deg.) and sweet granadilla seeds (Passiflora ligularis Juss.). Agronomía Colombiana, Bogotá, v.33, p.305-314, 2015.

ALEXANDRE, R. S.; LOPES, J. C.; TIRADENTES, A. T.; BRUCKNER, C. H.; OTONI, W.C. Metodologia de minienxertia em maracujazeiros. Revista Brasileira de Fruticultura, Jaboticabal, v.35, p.329-332, 2013.

ALEXANDRE, R.S.; BRUCKNER, C.H.; LOPES, J.C. Propagação do maracujazeiro: aspectos morfológicos, fisiológicos e genéticos. Alegre: EDUFES, 2009a. 208p.

ALEXANDRE, R.S.; COUTO, F.A.D.; DIAS, J.M.M.; OTONI, W.C.; CECON, P.R.; GOMES, B.S.; Factors affecting in vitro germination of passion fruit seeds. Plant, Cell, Culture and Micropropagation, Lavras, v.5, p.2735, 2009b.

ALEXANDRE, R.S.; JÚNIOR, A.W.; NEGREIROS, J.R.S.; PARIZZOTTO, A.; BRUCKNER, C.H. Germinação de sementes de genótipos de maracujazeiro. Pesquisa Agropecuária Brasileira, Brasília, DF, v.39, p.1239-1245, 2004.

ANTHONY, P.; OTONI, W.C.; POWER, J.B.; LOWE, K.C.; DAVEY, M.R. Protoplast isolation, culture, and plant regeneration from Passiflora. In: HALL, R.D. (Ed.). Plant cell culture protocols. Wageningen: Humana Press, 1999. p.169-181.

APPEZZATO-DA-GLÓRIA, B.; VIEIRA, M.L.C.; DORNELAS, M.C. Anatomical studies of in vitro organogenesis induced in leaf-derived explants of passionfruit. Pesquisa Agropecuária Brasileira, Brasília, DF, v.34, 2007-2013, 1999.

ARAUJO, C. A. T.; FALEIRO, F. G.; SEMPREBOM, M. S.; KRAUSE, W. Sobrevivência de plantas enxertadas de maracujazeiro em área com histórico de doenças causadas por Fusarium spp.no Mato Grosso. In: CONGRESSO BRASILEIRO DE FRUTICULTURA, 22., 2012, Bento Gonçalves. Anais... Bento Gonçalves: SBF, 2012. 4p.

ARAUJO, F.P.; MOUCO, M.A.C.; ONO, E.O.; RODRIGUES, J.D. Substratos e concentrações de ácido indolibutírico no enraizamento de estacas de Passiflora cincinnata Mast. Magistra, Cruz das Almas, v.22, n.1, p.21-27, 2010.
BERNACCI, L.C.; CERVI, A.C.; MILWARD-DEAZEVEDO, M.A.; NUNES, T.S.; IMIG, D.C.; MEZZONATO, A.C. Passifloraceae in Lista de Espécies da Flora do Brasil. Jardim Botânico do Rio de Janeiro, 2015. Disponivel em: $\leq$ http://floradobrasil.jbrj.gov.br/ jabot/floradobrasil/FB12506>.

BERNACCI, L.C.; MELETTI, L.M.M.; SOARESSCOTT, M.D.; PASSOS, I.R.S. Espécies de maracujá: caracterização e conservação da biodiversidade. In: Faleiro, F.G.; Junqueira, N.T.V.; Braga, M.F. (Ed.). Maracujá: germoplasma e melhoramento genético. Planaltina, DF: Embrapa Cerrados, 2005. p.559-586.

BRAGA, M.F.; JUNQUEIRA, N.T.V. Produção de mudas de maracujá-doce. Planaltina, DF: Embrapa Cerrados, 2003, 28p. (Documentos, 93).

BRAGA, M.F.; SANTOS, E.C.; JUNQUEIRA, N.T.V.; SOUSA, A.A.T.C.; FALEIRO, F.G.; REZENDE, L.N.; JUNQUEIRA, K.P.Enraizamento de estacas de três espécies silvestres de Passiflora. Revista Brasileira de Fruticultura, Jaboticabal, v.28, n.2, p.284-288, 2006.

BRAGLIA, L.; BENEDETTI, L.; GIOVANNINI, A.; NICOLETTI, F.; BIANCHINI, C.; PIPINO, L.; MERCURI, A. In vitro plant regeneration as a tool to improve ornamental characters in Passiflora species. Acta Horticulturae, The Hague, v.855, p.47-52, 2010.

CAVICHIOLI, J.C.; CORREA, L.S.; BOLIANI, A.C. Sobrevivência e desenvolvimento de seis espécies de maracujazeiros em área com histórico de morte prematura de plantas. Cultura Agronômica, Ilha Solteira, v.18, p.67-73, 2009a.

CAVICHIOLI, J.C.; CORRÊA, L.S.; BOLIANI, A.C.; OLIVEIRA, J.C. Uso de câmara úmida em enxertia hipocotiledonar de maracujazeiro-amarelo sobre três porta-enxertos. Revista Brasileira de Fruticultura, Jaboticabal, v.31, p.532-538, 2009b.

CHAVES, R. C.; JUNQUEIRA, N.T. V.; MANICA, I.; PEIXOTO, J. R.; PEREIRA, A. V.; FIALHO, J. F. Enxertia de maracujazeiro-azedo em estacas herbáceas enraizadas de espécies de passifloras nativas. Revista Brasileira de Fruticultura, Jaboticabal, v.26, p.120-123, 2004.

COSTA, A.M.; LIMA, H.C.; CARDOSO, E.R.; SILVA, J.R.; PADUA, J.G.; FALEIRO, F.G.; PEREIRA, R.C.A.; CAMPOS, G.A. Produção de mudas de maracujazeiro silvestre (Passiflora setacea). Planaltina, DF: Embrapa Cerrados, 2015. 6p. (Comunicado Técnico, 176). 
DELANOY, M.; VAN DAMMEA, P.; SCHELDEMAN, X.; BELTRAN, J. Germination of Passiflora mollissima (Kunth) LH Bailey, Passiflora tricuspis Mast. and Passiflora nov sp.seeds. Scientia Horticulturae, New York, v.110, p.198-203, 2006.

DORNELAS, M.C.; VIEIRA, M.L.C. Tissue culture studies on species of Passiflora. Plant Cell, Tissue and Organ Culture, Dordrecht, v.36, p.211-217, 1994.

ELLIS, R. T.; HONG. T.D.; ROBERTS, E.H. Handbook of seed technology for genebanks. Roma: International Board for Plant Genetic Resources, 1985. 456p.

ELLIS, R.H.; HONG, T.D.; ROBERTS, E.H. An intermediate category of seed storage behavior. 1. Coffee. Journal of Experimental Botany, Lancaster, v.41, p.1167-1174, 1990 .

EMBRAPA. Embrapa Cerrados. Maracujazeiros ornamentais com coloração de flores rosadas e azuladas. Disponível em: http://www. cpac.embrapa.br/lancamentoornamental $/>$ Citado em: 20 jun. 2016 d.

EMBRAPA. Lançamento da cultivar de maracujazeiro silvestre BRS Pérola do Cerrado. Disponível em: $\leq$ http://www.cpac.embrapa.br/lancamentoperola/ $>$ Citado em: 20 jun. 2016 a.

EMBRAPA. Lançamento oficial da cultivar de maracujazeiro silvestre BRS Sertão Forte (BRS SF). Disponível em: <http://www.cpac.embrapa.br/ lancamentosertaoforte/>. Acesso em: 20 jun. 2016b.

EMBRAPA. Memória do lançamento dos híbridos de maracujazeiro ornamental. Disponível em: $<$ http://www.cpac.embrapa.br/lancamentoornamental/>. Acesso em: 20 jun. $2016 \mathrm{c}$.

FALEIRO, F.G.; JUNQUEIRA, N.T.V. Passion fruit (Passiflora spp.) improvement using wild species. In: MARIANTE, A.S.; SAMPAIO, M.J.A.; INGLIS, M.C.V. The state of Brazil's plant genetic resources. Second National Report. Conservation and Sustainable Utilization for food and agriculture. Brasília, DF: Embrapa, 2009. p.101-106.

FALEIRO, F.G.; JUNQUEIRA, N.T.V.; BRAGA, M.F. Maracujá: demandas para a pesquisa. Planaltina, DF: Embrapa Cerrados, 2006. 54p.
FALEIRO, F.G.; JUNQUEIRA, N.T.V.; COSTA, A.M. Ações de pesquisa e desenvolvimento para o uso diversificado de espécies comerciais e silvestres de maracujá (Passiflora spp.). Planaltina, DF: Embrapa Cerrados, 2015. 26p. (Documentos, 329).

FALEIRO, F.G.; OLIVEIRA, E.J.; ANDRADE, S.R.M.; COSTA, A.M.; JUNQUEIRA, N.T.V.Biotecnologia na cultura do maracujazeiro. In: CANÇADO, G.M.A.; LONDE, L.N.(Ed.). Biotecnologia aplicada à agropecuária. Caldas: EPAMIG, 2012. p.401-440.

FERNANDO, J.A.; VIEIRA, M.L.C.; MACHADO, S.R.; APPEZZATO-DA-GLÓRIA, B. New insights into the in vitro organogenesis process: the case of Passiflora. Plant Cell, Tissue and Organ Culture, Dordrecht, v.91, p.3744, 2007.

FERREIRA, F.R. Germoplasma de maracujá. In: REUNIÃO TÉCNICA DE PESQUISAS EM MARACUJAZEIRO, 1998. Cruz das Almas: EmbrapaCNPMF, 1998. p.48-53.

FISCHER, I. H. Seleção de plantas resistentes e de fungicidas para o controle da "Morte Prematura" do maracujazeiro, causada por Nectria haematococca e Phytophathora parasítica. 2003. 60 f. Dissertação (Mestrado) - Escola Superior de Agricultura "Luiz de Queiroz”, Universidade de São Paulo, Piracicaba, 2003.

GARCIA, R.; PACHECO, G.; FALCAO, E.; BORGES, G.; MANSUR, E. Influence of type of explant, plant growth regeneration, salt composition of basal medium, and light on callogenesis and regeneration in Passiflora suberosa (Passifloraceae). Plant Cell, Tissue and Organ Culture, Dordrechet, v.106, p.47-54, 2011.

GONZALES-BENITO, M.E.; AGUILA, N.; AVILA, T. Germination and embryo rescue from Passiflora species seeds post-cryopreservation. CryoLetters, Lewes, v.30, p.142-147, 2009.

GURUNG, N.; SWAMY, G. S. K.; SARKAR, S. K.; BHUTIA, S. O.; BHUTIA, K. C. Studies on seed viability of passion fruit (Passiflora edulis f. flavicarpa Deg.). Journal of Crop and Weed, Mohanpur, v.10, p.484487, 2014.

GUZZO, F.; CEOLDO, S.; ANDREATTA, F.; LEVI, M. In vitro culture from mature seeds of Passiflora species. Scientia Agricola, Piracicaba, v.61, p.108-113, 2011.

JUNGHANS, T.G. (Ed.). Guia de plantas e propágulos de maracujazeiro. Brasília, DF: Embrapa. 2015. 95p. 
JUNGHANS, T.G.; SOUZA, A.S.; KOBAYASHI, A.K. Cultura de tecidos em maracujazeiros. In: LIMA, A.A.; CUNHA, M.A.P. Maracujá: produção e qualidade na passicultura. Cruz das Almas: Embrapa Mandioca e Fruticultura, 2004. p.97-106.

JUNQUEIRA, N.T. V.; CHAVES, R. C.; MANICA, I.; PEIXOTO, J. R.; PEREIRA, A. V.E FIALHO, J. F. Propagação do maracujazeiro azedo por enxertia em estacas herbáceas enraizadas de espécies de passifloras nativas. Planaltina: Embrapa Cerrados, 2002. 15p. (Boletim de Pesquisa e Desenvolvimento, 39)

JUNQUEIRA, N.T. V.; LAGE, D. A.; BRAGA, M. F.; PEIXOTO, J. R.; BORGES, T. A.; ANDRADE, S. R. M. de. Reação a doenças e produtividade de um clone de maracujazeiro-azedo propagado por estaquia e enxertia em estacas herbáceas de Passiflora silvestre. Revista Brasileira de Fruticultura, Jaboticabal, v.28, p.97-100, 2006.

JUNQUEIRA, N.T.V.; BRAGA, M.F.; FALEIRO, F.G.; PEIXOTO, J.R.; BERNACCI, L.C. Potencial de espécies silvestres de maracujazeiro como fonte de resistência a doenças. In: FALEIRO, F.G., JUNQUEIRA, N.T.V.e BRAGA, M.F. (Ed.). Maracujá: germoplasma e melhoramento genético. Planaltina, DF: Embrapa Cerrados, p.81-108. 2005.

JUNQUEIRA, N.T.V.; MANICA, I.; CHAVES, R. C.; LACERDA, C.S.; OLIVEIRA, J. A.; FIALHO, J. F. Produção de mudas de maracujazeiro-azedo por estaquia em bandejas. Planaltina, DF: Embrapa Cerrados, 2001. (Recomendações Técnicas, 42)

JUNQUEIRA, N.T.V.; ZACARONI, A.B.; SOUZA, M.A.; FALEIRO, F.G.; TEIXEIRA, L.P. Custo e estimativa de produtividade obtidos a partir de mudas de maracujazeiro-azedo tipo 'mudão' com diferentes idades. In: CONGRESSO BRASILEIRO DE FRUTICULTURA, 23., 2014, Cuiabá. Anais... Cuiabá: SBF, 2014. 4p.

LIMA, A. A.; CALDAS, R. C.; CUNHA, M. A. P.; SANTOS FILHO, H. P.Avaliação de porta-enxertos e tipos de enxertia para o maracujazeiro-amarelo. Revista Brasileira de Fruticultura, Jaboticabal, v.21, n.3, p.318321, 1999.

LIMA, D. M. D.; GOLOMBIESKI, E. R.; AYUB, R. A. Application of biotechnological processes to passion fruit culture. Ciência Rural, Santa Maria, v.30, p.359-363, 2000 .
LOPES, J.C.; BONO, G.M.; ALEXANDRE, R.S.; MAIA, V.M. Germination and vigor of passion fruit seeds in different estages of fruit maturation, substrate and presence or the aril. Ciência e Agrotecnologia, Lavras, v.31, n.5, p.1340-1346, 2007.

MACHADO, C.F.; FALEIRO, F.G.; JUNQUEIRA, N.T.V.; JESUS, O.N.; ARAÚJO, F.P.; GIRARDI, E.A. A enxertia do maracujazeiro: técnica auxiliar no manejo fitossanitário de doenças do solo. Cruz das Almas, BA: Embrapa Mandioca e Fruticultura, 2015. 15p. (Circular Técnica, 116).

MALDONADO, J.F.M. Utilização de porta-enxertos do gênero Passiflora para maracujazeiro-amarelo (Passiflora edulis Sims f. flavicarpa Deg.). Revista Brasileira de Fruticultura, Jaboticabal, v.13, p.51-54, 1991.

MELETTI, L. M. M.; BARBOSA, W.; VEIGA, R. F. A.; PIOR, R. Crioconservação de sementes de seis acessos de maracujazeiro. Revista Scientia Agrária Paranaensis, Marechal Cândido Rondon, v.6, p.13-20, 2007.

MELETTI, L. M. M.; NAGAI, V.Enraizamento de estacas de sete espécies de maracujazeiro (Passiflora spp). Revista Brasileira de Fruticultura, Jaboticabal, v.14, n.2, p.163168, 1992.

MENEZES, J.M.T.; OLIVEIRA, J.C. de; RUGGIERO, C.; BANZATTO, D. A. Avaliação da taxa de pegamento de enxertos de maracujá-amarelo sobre espécies tolerantes à "morte prematura de plantas". Científica, São Paulo, v.22, p.95-104, 1994.

MIRANDA, D.; CARRANZA, C.; CARDENAS, J.; RODRIGUEZ, A.; GUTIÉRREZ, I. Estado actual de la investigación en la propagación de Pasifloras en Colombia. In: CARRANZA, C.; OCAMPO, J.; MIRANDA, D.; PARRA, M.; CASTILLO, J.; RODRIGUEZ, A. Libro de Memorias-Congreso Latinoamericano de Pasifloras. Neiva: Corporación Cepass Colombia, 2013, v.1, p.7286.

MIRANDA, D.; FISHER, G.; CARRANZA, C.; MAGNITSKIY, S.; CASIERRA, F.; PIEDRAHÍTA, W.; FLÓREZ, L.H. Cultivo, poscosecha, y comercialización de las pasifloráceas en Colombia: maracuyá, granadilla, gulupa y curuba. Bogotá: Sociedad Colombiana de Ciencias Horticolas, 2009. 51p.

MORLEY-BUNKER, M.J.S. Seed coat dormancy in Passiflora species. Annual Journal of the Royal New Zeland Institute of Horticulture, Canterbury, v.8, p.7284, 1980. 
MORLEY-BUNKER, M.J.S. Some aspects of seed dormancy with reference to Passiflora spp.and other tropical and subtropical crops. London: University of London, 1974. 43p.

NEGREIROS, J.R.S.; WAGNER JÚNIOR, A.; ÁLVARES, V.S.; SILVA, J.O.C.; NUNES, E.S.; ALEXANDRE, R.S.; PIMENTEL, L.D.; BRUCKNER, C.H. Influência do estádio de maturação e do armazenamento pós-colheita na germinação e desenvolvimento inicial do maracujazeiroamarelo. Revista Brasileira de Fruticultura, Jaboticabal, v.28 p.21-24, 2006.

NOGUEIRA FILHO, G.C.; RONCATTO, G.; RUGGIEIRO, C.; OLIVEIRA, J.C. de; MALHEIROS, E.B. Propagação vegetativa do maracujazeiro-conquista de novas adesões. In: FALEIRO, F.G.; JUNQUEIRA, N.T.V.; BRAGA, M.F. (Ed.). Maracujá: germoplasma e melhoramento genético. Planaltina, DF: Embrapa Cerrados, 2005. p.341-358.

NOGUEIRA FILHO, G.C.; RONCATTO, G.; RUGGIERO, C.; OLIVEIRA, J.C.; MALHEIROS, E.B. Estudo da enxertia Hipocotiledonar do maracujazeiroamarelo sobre dois porta-enxertos, através da microscopia de varredura. Revista Brasileira de Fruticultura, Jaboticabal, v.32, p.647-652, 2010.

NOGUEIRA FILHO, G.C.; RONCATTO, G.; RUGGIERO, C.; OLIVEIRA, J.C.; MALHEIROS, E.B. Produção de mudas de maracujazeiro-amarelo por enxertia hipocotiledonar sobre sete espécies de passifloras. Revista Brasileira de Fruticultura, Jaboticabal, v.33, n.1, p.237245, 2011.

OLIVEIRA, J.A.; JUNQUEIRA, N.T.V.; PEIXOTO, J.R.; PEREIRA A.V.Efeito dos substratos artificiais no enraizamento e no desenvolvimento de estacas de maracujazeiro-azedo (Passiflora edulis Sims f. flavicarpa Deg.). Revista Brasileira de Fruticultura, Jaboticabal, v.24, p.505-508, 2002.

OLIVEIRA, J.C. e RUGGIERO, C. Aspectos sobre o melhoramento do maracujazeiro amarelo. In: RUGGIERO, C. (Ed.). Maracujá: do plantio à colheita. Jaboticabal: FUNEP, 1998. p.291-310.

OLIVEIRA, J.C.; NAKAMURA, K.; MAURO, A.O.; CUNHA, M.A.P.Aspectos gerais do melhoramento do maracujazeiro. In: SÃO JOSÉ, A.R. Maracujá: produção e mercado. Vitória da Conquista: DFZ-UESB, 1994. p.27-37.
O LIVEIRA， R.P.; S CIVITTAR O, W.B.; VASCONCELLOS, L.A.B.C. Avaliação de mudas de maracujazeiro em função do substrato e do tipo de bandeja. Scientia Agrícola, Piracicaba, v.50, n.2, p.261266, 1993.

OSIPI, E.A.F.; LIMA, C.B.; COSSA, C.A. Influência de métodos de remoção do arilo na qualidade fisiológica de sementes de Passiflora alata Curtis. Revista Brasileira de Fruticultura, Jaboticabal, v.27, n.2, p.680-685, 2011. Volume Especial

OSPINA, J.A.; GUEVARA, C.L.; CAICEDO, L.E.; BARNEY, V. Effects of moisture on Passiflora seed viability after immersion in liquid nitrogen. In: ENGELMANN, F.; HIROKO, T. (Ed.). Cryopreservation of tropical plant germplasm: current research progress and application japan international research center for agricultural sciences. Tsukuba: Japan International Research Center for Agricultural Sciences, 2000. p.384-388

OTONI, W.C. Hibridização e embriogênese somática e transformação genética em espécies de Passiflora. 1995. 198 f. Tese (Doutorado em Genética e Melhoramento)Universidade Federal de Viçosa, Viçosa. 1995.

OTONI, W.C.; PAIM PINTO, D.L.; ROCHA, D.I.; VIEIRA, L.M.; DIAS, L.L.C.; SILVA, M.L.; SILVA, C.V.; LANI, E.R.G.; SILVA, L.C.; TANAKA, F.A.O. Organogenesis and somatic embryogenesis in passionfruit (Passiflora sps.). In: ASLAM, J.; SRIVASTAVA, O.S.; SHARMA, M.P. (Ed.). Somatic embryogenesis and gene expression. New Delhi: Narosa Publishing House, 2013. p 1-17

OZAROWSKI, M.; THIEM, B. Progress in micropropagation of Passiflora spp.to produce medicinal plants: a mini-review. Revista Brasileira de Farmacognosia, São Paulo, v.23, p.937-947, 2013.

PACHECO, G.; GARCIA, R.; LUGATO, D.; VIANNA, M.; MANSUR, E. Plant regeneration, callus induction and establishment of cell suspension cultures of Passiflora alata Curtis. Scientia Horticulturae, New York, v.144, p.42-47, 2012.

PACHECO, G.; SIMÃO, M.J.; VIANNA, M.G.; GARCIA, R.O.; VIEIRA, M.L.C.; MANSUR, E. In vitro conservation of Passiflora-A review. Scientia Horticulturae, New York, v.211, p.205-311, 2016. 
PÁDUA, J. G.; SCHWINGEL, L.C.; MUNDIM, R.C.; SALOMÃO, A.N.; ROVERIJOSÉ, S.C.B. Emergência de sementes de Passiflora setacea e dormência induzida pelo armazenamento. Revista Brasileira de Sementes, Brasília, DF, v.33, n.1, p.80-85, 2011.

PARMESSUR, Y.; ALJANABI, S.; SAUMTALLY, S.; DOOKUN-SAUMTALLY, A. Sugarcane yellow leaf virus and sugarcane yellows phytoplasma: elimination by tissue culture. Plant Pathology, New Delhi, v.51, p.561-566. 2002.

PASSOS, I.R.S.; BERNACCI, L.C. Cultura de tecidos aplicada à manutenção de germoplasma in vitro e ao melhoramento genético do maracujá (Passiflora spp.) In: FALEIRO, F.G.; JUNQUEIRA, N.T.V.; BRAGA, M.F. (Ed.). Maracujá: germoplasma e melhoramento genético. 2005. p.361-383.

PASSOS, I.R.S.; MATOS, G.V.C.; MELETTI, L.M.M.; SOARES-SCOTT, M.D.; BERNACCI, L.C.; VIEIRA, M.A.R.., Utilização do ácido giberélico para a quebra de dormência de sementes de Passiflora nitida Kunth germinadas in vitro. Revista Brasileira de Fruticultura, Jaboticabal, v.26, n.2, p.380-381, 2004.

PAULA, M.S.; FALEIRO, F.G.; JUNQUEIRA, K.P.; BELLON, G.; JUNQUEIRA, N.T.V.; BRAGA, M.F.; PEIXOTO, J.R. Diversidade genética de espécies de Passiflora, potenciais fontes de resistência a doenças, com base em marcadores RAPD. In: FALEIRO, F.G.; JUNQUEIRA, N.T.V.; BRAGA, M.F.; PINTO, A.C.Q.; SOUSA, E.S. (Eds.) IV Reunião Técnica de Pesquisas em Maracujazeiro - Trabalhos apresentados. Planaltina,DF: Embrapa Cerrados, 2005. p. 100-104.

PEREIRA, K.J.C.; DIAS, D.C.F.S. Germinação e vigor de sementes de maracujá-amarelo (Passiflora edulis Sims. f. flavicarpa Deg.) submetidas a diferentes métodos de remoção da mucilagem. Revista Brasileira de Sementes, Pelotas, v.22, p.288-291, 2000.

PINTO, D.L.P.; ALMEIDA, A.M.R.; RÊGO, M.M.; SILVA, M.L.; OLIVEIRA, E.J.; OTONI, W.C. Somatic embryogenesis from mature zygotic embryos of commercial passionfruit (Passiflora edulis Sims) genotypes. Plant Cell, Tissue and Organ Culture, Dordrecht, v.107, p.521-530, 2011.

PIPINO, L.; BRAGLIA, L.; GIOVANNINI, A.; FASCELLA, G.; MERCURI, A. In vitro regeneration of Passiflora species with ornamental value. Propagation of Ornamental Plants, Sofia, v.8, p.47-49, 2008.
PRAMMANEE, S.; THUMJAMRAS, S .; CHIEMSOMBAT, P.; PIPATTANAWONG, N.Efficient shoot regeneration from direct apical meristem tissue to produce virus-free purple passion fruit plants. Crop Protection, Oxford, v.30, p.1425-1429, 2011.

REGO, M.M.; REGO, E.R.; NATTRODT, L.P.U.; BARROSO, P.A.; FINGER, F.L.; OTONI, W. C. Evaluation of different methods to overcome in vitro seed dormancy from yellow passion fruit. African Journal of Biotechnology, Nairobi, v.13, n.36, p.3657-3665, 2014.

REIS, L.B.; SILVA, M.L.; LIMA, A.B.P.; OLIVEIRA, M.L.P.; PAIM-PINTO, D.L.; LANI, E.R.G.; OTONI, W.C. Agrobacterium rhizogenes-mediated transformation of passionfruit species: Passiflora cincinnata and P.edulis f. flavicarpa. Acta Horticulturae, The Hague, v.738, p.425-431, 2007.

REZENDE, O.P.; PIMENTEL, L.D.; ALVES, T.L.; MORGADO, M.A.D. Estaquia de maracujá amarelo (Passiflora edullis sims f. flavicarpa Deg.) em miniestufas constituídas de garrafas de poliestireno, avaliando-se cinco substratos. Revista Ceres, Viçosa, MG, v.52, p.267-273, 2005.

RIBEIRO, L. M.; PEIXOTO, J. R.; ANDRADE, S. R. M. de; FONSECA, R. S.; VIEIRA, L. M.; PEREIRA, W. V.S. Microenxertia ex vitro para eliminação do vírus CABMV em maracujá-azedo. Pesquisa Agropecuária Brasileira, Brasília, DF, v.43, p.589-594, 2008.

ROCHA, D. I.; PINTO, D. L. P.; VIEIRA, L. M.; TANAKA, F. A. O.; DORNELAS, M. C.; OTONI, W.C. Cellular and molecular changes associated with competence acquisition during passion fruit somatic embryogenesis: ultrastructural characterization and analysis of $S E R K$ gene expression. Protoplasma, Wien, v.253, p.595-609, 2016.

ROCHA, D.I.; MONTE-BELLO, C.C.; DORNELAS, M.C. Alternative induction of de novo shoot organogenesis or somatic embryogenesis from in vitro cultures of mature zygotic embryos of passion fruit (Passiflora edulis Sims) is modulated by the ratio between auxin and cytokinin in the medium. Plant Cell, Tissue and Organ Culture, Dordrecht, v.120, p.1087-1098, 2015.

ROCHA, D.I.; VIEIRA, L.M.; TANAKA, F.A.; SILVA, L.C.; OTONI, W.C. Somatic embryogenesis of a wild passion fruit species Passiflora cincinnata Masters: histocytological and histochemical evidences. Protoplasma, Wien, v.249, p.747-758, 2012. 
RONCATTO, G.; ASSIS, G.M.L.; OLIVEIRA, T.K.; LESSA, L.S. Aspectos vegetativos de combinações copa/ porta-enxerto em maracujazeiro. Revista Brasileira de Fruticultura, Jaboticabal, v.33, n.3, p.791-797, 2011a.

RONCATTO, G.; NOGUEIRAFILHO, G.C., RUGGIERO, C., OLIVEIRA, J.C.; MARTINS, A.B.G. Enraizamento de estacas herbáceas de diferentes espécies de maracujazeiro. Revista Brasileira de Fruticultura, Jaboticabal, v.30, n.4, p.1094-1099, 2008b.

RONCATTO, G.; NOGUEIRA FILHO, G.C.; RUGGIERO, C.; OLIVEIRA, J.C.; MARTINS, A.B.G. Enraizamento de estacas de espécies de maracujazeiro (Passiflora spp.) no inverno e no verão. Revista Brasileira de Fruticultura, Jaboticabal, v.30, n.4, p.1089-1093, 2008a.

RONCATTO, G.; OLIVEIRA, J.C.; RUGGIERO, C.; NOGUEIRA FILHO, G.C.; CENTURION, M.A.P.C.; FERREIRA, F.R. Comportamento de maracujazeiros (Passiflora spp.) quanto à morte prematura. Revista Brasileira de Fruticultura, Jaboticabal, v.26, n.3, p.552554, 2004.

ROSA, Y.B.C.J.; MONTE BELLO, C.C.; DORNELAS, M.C. Species-dependent divergent responses to in vitro somatic embryo induction in Passiflora spp. Plant Cell, Tissue and Organ Culture, Dordrecht, v.120, p.69-77, 2015.

RUGGIERO, C. Enxertia do maracujazeiro. In: SÃO JOSÉ, A. R.; FERREIRA, F. R.; VAZ, R. L. (Ed.). A cultura do maracujá no Brasil. Jaboticabal: FUNEP, 1991. p.43-60.

RUGgiero, C.; OLIVEIRA, J. C. Enxertia do maracujazeiro. In: SIMPÓSIO BRASILEIRO SOBRE A CULTURA DO MARACUJAZEIRO, 5., 1998, Jaboticabal. Anais... Jaboticabal: FUNEP, 1998. p.7092.

SALOMÃO, L.C.C.; PEREIRA, W.E.; DUARTE, R.C.C.; SIQUEIRA, D.L.D. Propagação por estaquia dos maracujazeiros doce (Passiflora alata Dryand.) e amarelo (P.edulis f. flavicarpa Deg.). Revista Brasileira de Fruticultura, Jaboticabal, v.24, n.1, p.163-167, 2002.

SANTOS FILHO, H. P. Doenças do sistema radicular do maracujazeiro. In: SIMPÓSIO BRASILEIRO SOBRE A CULTURA DO MARACUJAZEIRO, 5., Jaboticabal. Anais... Jaboticabal: FUNEP, 1998. p.244-254.
SANTOS, C.H.B.; CRUZ NETO, A.J.; SOARES, T.L.; OLIVEIRA, E.J.; JESUS, O.N.; GIRARDI, E.A. Porta-enxertos e fixadores de enxerto para enxertia hipocotiledonar de maracujazeiro azedo. Ciência Rural, Santa Maria, v.46, n.1, p.30-35, 2016 b.

SANTOS, F.C.; RAMOS, J.D.; PASQUAL, M.; REZEND, J.C.; SANTOS, F.C.; VILLA, F. Micropropagação do maracujzaeiro do sono. Revista Ceres, Viçosa, MG, v.57, p.112-117, 2010.

SANTOS, J. L.; MATSUMOTO, S.N.; D’AREDE, L.O.; LUZ, I.S.D.; VIANA, A.E.S. Vegetative propagation of cuttings of Passiflora cincinnata mast. in different commercial substrates and containers. Revista Brasileira de Fruticultura, Jaboticabal,v.34, n.2, p.581-588, 2012 b.

SANTOS, M.C.; SOUSA, G.R.L.; SILVA, J.R.; SANTOS, V.L.M. Efeito da temperatura e do substrato na germinação de sementes de maracujá (Passiflora edulis Sims. var. flavicarpa Deg.). Revista Brasileira de Sementes, Pelotas, v.21, p.1-6, 1999.

SANTOS, T.M.; FLORES, P.S.; OLIVEIRA, S.P.; SILVA, D.F.P.S.; BRUCKMER, C.H. Tempo de armazenamento e métodos de quebra de dormência em sementes do maracujá-de-restinga. Revista Brasileira de Agropecuária Sustentável, Viçosa, MG, v.2, n.1, p.26-31. 2012a.

SÃO JOSÉ, A.R. Propagação do maracujazeiro. In: SÃO JOSÉ, A. R.; FERREIRA, F. R.; VAZ, R. L. A cultura do maracujá no Brasil. Jaboticabal: FUNEP/UNESP, 1991. p.25-41.

SEMPREBOM, M. S.; FALEIRO, F. G.; ARAUJO, C. A. T.; PRADO, L. L. do.; HADDAD, F.; JUNQUEIRA, N.T. V.Tecnologia de mudas enxertadas de maracujazeiro azedo para controle de doenças causadas por Fusarium spp.no Mato Grosso - a experiência da Coopernova. In: CONGRESSO BRASILEIRO DE FRUTICULTURA, 22., 2012, Bento Gonçalves. Anais... Bento Gonçalves: SBF, 2012. 4p.

SILVA, C.V.; OLIVEIRA, L.S.; LORIATO, V.A.P.; SILVA, L.C.; CAMPOS, J.M.S.; VICCINI, L.F.; OLIVEIRA, E.J.; OTONI, W.C. Organogenesis from root explants of commercial populations of Passiflora edulis Sims and a wild passionfruit species, P.cincinnata Masters. Plant Cell, Tissue and Organ Culture, Dordrecht, v.107, p.407-416, 2011. 
SILVA, F.M.; CORRÊA, L.S.; BOLIANI, A.C.;SANTOS, P.C. Enxertia de mesa de Passiflora edulis Sims f. flavicarpa Deg. sobre Passiflora alata Curtis, em ambiente de nebulização intermitente. Revista Brasileira de Fruticultura, Jaboticabal, v.27, p.98-101, 2005.

SILVA, M.L.; PINTO, D.L.P.; GUERRA, M.P.; FLOH, E.I.S.; BRUCKNER, C.H.; OTONI, W.C.A novel regeneration system for a wild passion fruit species (Passiflora cincinnata Mast.) based on somatic embryogenesis from mature zygotic embryos. Plant Cell, Tissue and Organ Culture, Dordrecht, v.99, p.47-54, 2009.

SILVA, R.M. Enxertia de cultivares de maracujazeiro azedo sobre Passiflora foetida L.: desempenho agronômico das cultivares, caracterização morfoagronômica, variabilidade genética do porta enxerto e resistência à fusariose. 2016. 112f. Tese (Doutorado em Agronomia) - Programa de Pós-graduação em Fitotecnia, Universidade Federal Rural do Semi-Árido, Mossoró, 2016.

SILVA, R.P.; PEIXOTO, J.R.; JUNQUEIRA, N.T.V.Influência de diversos substratos no desenvolvimento de mudas de maracujazeiro azedo (Passiflora edulis Sims f. flavicarpa Deg.). Revista Brasileira de Fruticultura, Jaboticabal, v.23, n.2, p.377-381, 2001.

SILVA-NETO, S.P.; ANDRADE, S.R.M. Cultura de tecidos vegetais: princípios e aplicações. In: FALEIRO, F.G.; ANDRADE, S.R.M.; REIS JÚNIOR, F.B. (Ed.). Biotecnologia: estado da arte e aplicações na agropecuária. Planaltina, DF: Embrapa Cerrados. 2011. p.409-434.

SIQUEIRA, D. L.; PEREIRA, W. E. Propagação. In: BRUCKNER, C. H.; PICANÇO, M. C. (Ed.). Maracujá: tecnologia de produção pós-colheita, agroindustria, mercado. Porto Alegre: Cinco Continentes, 2001. p.85137.

SOUZA, J.S.I.; MELETTI, L.M.M. Maracujá: espécies, variedades e cultivo. Piracicaba: FEALQ, 1997. 179p.

SOUZA, P.V.D.; CARNIEL, E.; FOCHESATO, M. L. Efeito da composição do substrato no enraizamento de estacas de maracujazeiro azedo. Revista Brasileira de Fruticultura, Jaboticabal, v.28, n.2, p.276-279, 2006.
VAZ, C. F.; PEIXOTO, J.R.; JUNQUEIRA, N.T.V.; BRAGA, M.F.; SANTOS, E.C.; FONSECA, K.G.; JUNQUEIRA, K.P.Enraizamento de espécies silvestres de maracujazeiro utilizando cinco doses de ácido indolilbutírico. Revista Brasileira de Fruticultura, Jaboticabal, v.31, n.3, p.816-822, 2009.

VEIGA-BARBOSA, L.; MIRA, S.; GONZÁLEZBENITO, M. E.; SOUZA, M. M.; MELETTI, L. M. M.; PÉREZ-GARCÍA, F. Seed germination, desiccation tolerance and cryopreservation of Passiflora species. Seed Science and Technology, Delhi, v.41, p.89-97, 2013.

VIANA, M.L. Enraizamento de estacas de cultivares de maracujazeiro ornamental. 2016. 26 p. Monografia (Trabalho de Conclusão de Curso) - Faculdades Integradas, Planaltina, DF, 2016.

VIEIRA, L.M.; ROCHA, D.I.; TAQUETTI, M.F.; SILVA, L.C.; CAMPOS, J.M.S.; VICCINI, L.F.; OTONI, W.C. In vitro plant regeneration of Passiflora setacea D.C. (Passifloraceae): the influence of explant type, growth regulators, and incubation conditions. In Vitro Cellular \& Developmental Biology - Plant, New York, v.50, p.738-745, 2014.

VIEIRA, M.L.C.; OLIVEIRA, E.J.; MATTA, F.P.; PÁDUA, J.G.; MONTEIRO, M. Métodos biotecnológicos aplicados ao melhoramento genético do maracujá. In: FALEIRO, F.G.; JUNQUEIRA, N.T.V.; BRAGA, M.F. (Ed.). Maracujá: germoplasma e melhoramento genético. Planaltina, DF: Embrapa Cerrados, 2005. p.411-453.

VIVIAN, R.; SILVA, A. A.; GIMENES, J.; FAGAN, E. B.; RUIZ, S. T.; LABONIA, V.Dormência em sementes de plantas daninhas como mecanismo de sobrevivência: breve revisão. Planta Daninha, v.26, p.695-706, 2008.

WAGNER JÚNIOR, A.; ALEXANDRE, R.S.; NEGREIROS, J.R.D.S.; PIMENTEL, L.D., SILVA, J.O.D.C.; BRUCKNER, C. H. Effects of substrate on germination and initial growth of yellow passion fruit (Passiflora edulis Sims f. flavicarpa Deg). Ciência e Agrotecnologia, Lavras, v.30, n.4, p.643-647, 2006.

ZUCARELI, V.; FERREIRA, G.; AMARO, A.C.E.; ARAÚJO, F.P.D. Photoperiod, temperature and plant growth regulators on germination of Passiflora cincinnata seeds. Revista Brasileira de Sementes, Pelotas, v.31, p.106-114, 2009. 